\title{
Reconciling Life Cycle Environmental Impacts with Ecosystem Services: A Management Perspective on Agricultural Land Use
}

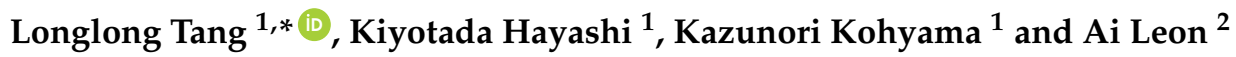 \\ 1 Institute for Agro-Environmental Sciences, National Agriculture and Food Research Organization, \\ 3-1-3 Kannondai, Tsukuba, Ibaraki 305-8604, Japan; hayashi@affrc.go.jp (K.H.); kohyama@affrc.go.jp (K.K.) \\ 2 Graduate School of Energy Science, Kyoto University, Yoshida-Honmachi, Sakyo-ku, Kyoto 606-8501, Japan; \\ Aislg@hotmail.com \\ * Correspondence: tanglonglong@affrc.go.jp; Tel.: +81-29-838-8272
}

Received: 30 January 2018; Accepted: 24 February 2018; Published: 28 February 2018

\begin{abstract}
Impacts on ecosystem services that are related to agricultural land use greatly differ depending on management practices employed. This study aimed to reveal issues associated with evaluating ecosystem services related to land use at the management level during life cycle assessment (LCA) and to consider future challenges. Firstly, a relationship between agricultural ecosystem services and management practices was outlined. Then, a survey was performed to disclose the current status of assessment of impact of land use in agricultural LCA case studies that compared between different management practices. In addition, this study also investigated how management practices have been differently considered by factors that characterize ecosystem services that are related to land use. The results show that the number of agricultural LCA cases where land use impacts instead of land areas were assessed was still small. The results of limited LCA case studies, which using factors could differentiate between various management practices, suggest that although organic farming methods have been employed over large land areas, lower impact may be caused by agricultural land use. For factors developed in existing research, services related to soil quality, and some of the regulatory services were considered, those unique to agriculture were missing. Although most of factors were calculated at levels of intensity or land use type, some of them were based on a process-based model that could consider management practices. In the future, factors that characterize the impacts of land use on ecosystem services, such as carbon storage and erosion prevention, will need to be calculated at the management level. For ecosystem services, such as habitat conservation and pollination, further efforts in accumulating evaluation case studies that collect and accumulate foreground data are important.
\end{abstract}

Keywords: agricultural product system; characterization factor; ecosystem service; land use; life cycle impact assessment; management practice

\section{Introduction}

Quantification of ecosystem services, defined as ecosystem functions that benefit the society, has recently received considerable attention $[1,2]$ and can be used during the selection of land use scenarios and ecosystem conservation [1]. From an agricultural standpoint, the amount of research conducted regarding the clarification $[3,4]$ and quantification $[5,6]$ of ecosystem services has increased. Various management practices (e.g., application of pesticides and chemical fertilizers, tillage methods, cultivation periods, and water management methods) conducted for agricultural production significantly influence agricultural ecosystem services, such as soil carbon storage, soil erosion prevention, and wildlife habitat conservation [3]. For example, winter flooding in paddy fields 
is specifically done to provide habitat conservation services [7-9]. The Economics of Ecosystems and Biodiversity (TEEB) [10] has been used for evaluating the performance of agricultural systems by evaluating ecosystem services. Quantification of ecosystem services contributes to the selection of management practices for farmlands.

Life cycle assessment (LCA) is frequently conducted for comparing the environmental impacts of various agricultural production systems. For example, organic and conventional production systems have been assessed comparatively [11,12]. Depending on the setting of the functional unit, environmental impacts per land area or agricultural product weight have been assessed [13]. In the case of foods and other agricultural products, environmental labels are used as a tool designed to appeal to consumers in support of environmentally-minded management practices [14]. Studies on the Product Environmental Footprint (PEF) in Europe provide an example [15]. The environmental labels are based on LCA techniques [16]. The functional unit is the weight of a food or an agricultural product, whereas land use is chosen as an impact category indicating the influences of land management practices on biodiversity and/or ecosystem services.

However, this is only the beginning when it comes to evaluating ecosystem services as a part of LCA $[17,18]$. Estimating factors that characterize the impacts of land use on ecosystem services is currently being prioritized [18-20]. Human land uses generate environmental impacts through land occupation, which focuses on the impacts during the period of the occupation, and land use change, where the impacts caused by the transformation of the properties of land have been considered [21]. This study focused on land occupation for revealing differences in environmental impacts depending on agricultural management practices.

Factors that characterize the impacts of land use are primarily developed by the UNEP/SETAC life cycle initiative project $[19,22]$. Most of the factors that characterize the impacts of land use are classified by the particular type of land use (e.g., arable land and permanent cropland) and do not differentiate between management practices. Land Use Indicator Value Calculation in Life Cycle Assessment (LANCA) $[5,23]$ estimates factors that consider the intensity of land management (intensive and extensive) but focuses on ecosystem services related to soil quality only. Vidal-Legaz et al. [24] reviewed and compared existing land use models to highlight important aspects in the models, but differences between management practices have not been discussed in this study.

Although development of factors that characterize land use is limited, LCA case studies have been conducted to compare different management practices. Although a review of these LCA case studies examined the differences between organic and conventional farming practices [25], the primary focus of these studies has been on the inputs (pesticides, fertilizers, etc.) and outputs (GHGs, water discharge, etc.) to be evaluated. Measures of biodiversity and ecosystem services, which are derived from land use, are important for comparative evaluation; however, the methods that are used to obtain these measurements remain under development and are not organized [25]. Therefore, effects of using factors that characterize land use depending on differences in management practices remain unclear.

Determining environmental impacts of management practices is important for the comparative assessment of management practices in LCA and for developing environmental labels that are based on LCA. In agricultural LCA in particular, differences in management practices at farmlands must be considered when assessing the impacts of land use on ecosystem services. However, it is unclear how management practices are considered in the assessment of impacts of land use and in the development of an impact factor of land use in LCA. This study aims to provide answers to the following questions by performing two reviews of LCA literatures.

- How are impacts of land use on ecosystem services assessed in LCA cases where agriculture/food is the subject? How does a difference in management practice affect assessment results?

- Are differences in management practices considered during the development of impact factors of land use on ecosystem services? What are the issues that should be addressed when calculating a factor in consideration of the management practice? 


\section{Agricultural Ecosystem Services}

In order to answer the above questions, a relationship between agricultural ecosystem services and management practices, and models for quantifying the ecosystem services were outlined, before investigating articles in research field of LCA.

\subsection{Agricultural Ecosystem Services and Related Management Practices}

According to TEEB [26], ecosystem services are classified into four categories: provision (e.g., food), regulatory (e.g., water purification and soil carbon storage), habitat or supporting (e.g., habitat conservation), and cultural services (e.g., recreation). Regarding agriculture, Power [3] demonstrated the nature of the relationship between agricultural activities and ecosystem services on different scales while considering the relationships between agriculture and surrounding ecosystems. Huang et al. [4] reviewed research in two scientific communities, which focus on the multi-functionality of agriculture and ecosystem services, to classify agricultural ecosystems in a manner that provided greater consensus. Table 1 shows main agriculture-related ecosystem services and differences in agricultural activities in relation to these ecosystem services based on the studies mentioned above. Ecosystem services provided by agriculture are mainly provision and cultural services. Conversely, agriculture receives the benefits of pollination and pest control from surrounding ecosystems. In addition, regulatory services, such as carbon storage and erosion prevention, are provided by both agriculture and surrounding ecosystems.

Ecosystem services are closely associated with management activities of production systems [3,27]. One ecosystem service may be influenced by multiple management activities (Table 1). For example, soil carbon storage and soil erosion prevention can be influenced by tillage methods and cropping systems (crop rotation, cultivation periods, etc.). However, they are discretely affected by the removal of plant debris and organic matter as well as by cultivation methods on slopes. Furthermore, habitat conservation services are affected by pesticide application, furrow weed management, and landscape management. Conversely, one management practice may affect multiple ecosystem services. For example, although the application of large amounts of chemical fertilizers increases food supply, it also plays a role in water purification, nutrient circulation, and habitat conservation.

As described above, understanding relationships among various ecosystem services and management practices is important during evaluation of different management practices. For example, while evaluating the soil carbon storage service, when considering fertilizer management as well as plowing, water management, and rotation is necessary. Conversely, when evaluating the impact of ecosystem services based on specific management practices, such as winter flooding, there is the need to consider the role of habitat conservation services. 
Table 1. The relationship among ecosystem services and primary management practices.

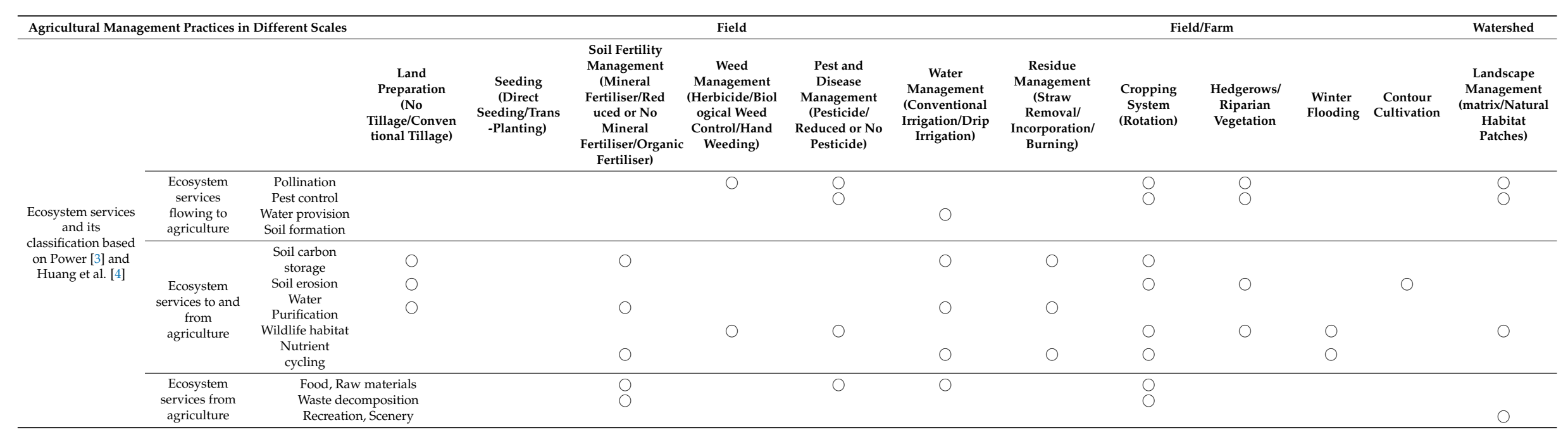




\subsection{Models for Quantifying Ecosystem Services}

The assessment of ecosystem services is usually composed of two steps: quantification of ecosystem services provided through ecosystem functions (functional quantification) and its evaluation by measuring benefits of these ecosystem services to the society [18]. Because the latter is performed using economic evaluation methods [28,29], here, models only used in the former step are discussed due to the current study focuses on points that express differences in management practices.

Othoniel et al. [18] have reviewed evaluation models currently used for quantification of ecosystem functions. That study revealed that few quantitative evaluation models have been developed for habitat or supporting services, such as pest and disease control, soil formation, and habitat conservation. In addition, they classified evaluation models into three types based on the results of previous studies [30-33]. The three types are proxy-based (use of proxy indicators such as land use type, etc.) [30,34], process modeling-based (linear or non-linear modeling based on processes by which ecosystem services are provided) [5], and primary data-based (based on monitoring data) models [35].

To differentiate management practices, both process modeling- and primary data-based models are available. For example, the Rothamsted carbon (RothC) model [36,37] can quantify soil carbon storage by considering differences in farmland management practices, such as the tillage method, flood season (in the case of rice fields), and residual handling of crops. The water erosion prediction project (WEPP) [38] and LANCA $[5,23]$ can be used for evaluating soil erosion prevention by considering tillage methods, crop types, cultivation periods, and slope. For wildlife habitat conservation, for which quantification is comparatively difficult, assessment methods that are based on field work are often used [39].

In addition, because interactions occur among ecosystem services, the development of an integrated model that would consider the multi-functionality of ecosystems is important for conducting an ecosystem service tradeoff analysis $[40,41]$. There are comparatively few such integrated models, such as the use of artificial intelligence for ecosystem services (ARIES) [42] and multi-scale integrated models of ecosystem services (MIMES) [41]. The Integrated Valuation of Ecosystem Services and Tradeoffs (InVEST) [40] can be used for assessing multiple ecosystem services and is also suitable in cases wherein there are comparatively few data, although there are limits to analyzing temporal changes in ecosystem services [43]. However, integrated models are limited in their inability to depict ecosystem service items in an exhaustive manner.

\section{Survey Methods}

\subsection{Survey (1) Assessment of Impact of Land Use in Agricultural LCA Case Studies}

A survey of LCA case studies, in which agricultural production systems were comparatively evaluated, was performed for clarifying current conditions and research needs related to the assessment of impacts of land use to focus on differences among management practices. The investigation methods are shown below.

First, Scopus ${ }^{\circledR}$ was searched by using the keywords "life cycle assessment", "land use", and "agriculture or food" and 600 hits were obtained (review articles were excluded).

Next, the abstracts of these 600 documents were investigated, and finally, 111 articles were remained. Regarding the criteria for screening, only articles that satisfy all of the following three criteria were selected: (i) the article performed an LCA case study; (ii) a food or an agricultural product is the subject of the case study; (iii) land use impact category is included in the case study.

Lastly, all 111 articles were reviewed to survey their assessment methods of land use impact focusing on adopted index, type of ecosystem services which considered, and the methods to quantify the ecosystem services.

\subsection{Survey (2) Factors That Characterize Ecosystem Services for the Assessment of the Impact of Land Use}

Another survey of peer-reviewed articles, which developed factors that characterize impacts of land use, was performed to clarify research problems when these factors are focused on different 
management practices. Both factors that characterize the impacts of land use on ecosystem services and on biodiversity were considered to grasp the whole picture of the impact of land use.

First, Scopus ${ }^{\circledR}$ was searched by using keywords "life cycle impact assessment" and "land use" and 159 hits were obtained (review articles were excluded). Then, these were narrowed to 108 articles using the keywords "factor" or "indicator".

Next, these 108 articles were then investigated to identify finally 21 articles to be included in the present review. The screening was performed by using following two criteria: (i) impact on ecosystem due to land use in LCA is focused in the article; (ii) impact factors are estimated.

Lastly, all 21 articles were reviewed to survey their assessment methods of impact factors focusing on the considered ecosystem services, levels of estimated factors (i.e., land use type, intensity, and management practice), and the modeling approach used in calculation of the factors.

\section{Results}

\subsection{Results and Insights from Survey (1)}

In a total of 111 cases, 92 cases had impacts of land use that were assessed based on land use area. The 19 cases where impacts on ecosystems were assessed included 5 and 10 cases that only focused on ecosystem services and biodiversity, respectively, and four cases where both were assessed (Table S1). The number of agricultural LCA cases where land use impacts instead of land area were assessed was still small, and most of the analyses were performed in or after 2010. It shows that impacts on ecosystem are increasingly required to be taken into consideration during the assessment of impacts of land use.

Many cases involving the assessment of impact on ecosystem services used soil-quality-related indicators (e.g., soil organic carbon and erosion) [44-52]. This reveals that assessed items are still limited when compared with the assessment of diverse agriculture-related ecosystem services (Table 1). Existing factors were used for the assessment of ecosystem service items in only one study [45]. In most of the studies [46-48], local soil, geography, and climatic data were used in a proposed calculation model (LANCA, universal soil loss equation (USLE), etc. in the case of soil erosion) to reflect locality and the influence of management practices. This can be said to have exposed the current status in which existing ecosystem service factors for land use are not yet practical indicators of differences in management practice.

Here, focusing on the studies that compared differences between environmental impacts of distinct management systems of production of a single agricultural product or food, we examined whether environmental impacts of land use are shown based on management practice when the influence of two systems were compared. In a total of 19 cases where the impacts on ecosystems were assessed, seven cases (Table 2) compared the impact of land use among management systems. Table 2 shows ratios of results between organic (or extensive) and conventional (or intensive) farming systems on both stages of land use inventory and land use impact. Two cases $[49,53]$ using CFs that do not reflect differences in management practices indicated that organic farming systems had a large impact. In the remaining five cases, using factors could differentiate the impacts of various management practices, on the stage of inventory, the area of land used for organic farming systems was 1.0-3.2 times larger than that used for conventional farming systems. However, in cases on the stage of impact, 1 case [54] indicated that organic farming systems had a large impact, whereas three cases $[11,12,55]$ indicated that this impact was small. In the three cases, factors that characterize the effects of land use due to organic farming practices are very small. Therefore, the impact of organic farming systems was smaller, although the area used for organic farming was large. The studies suggest that there may be a reversal in the relationship of production systems depending on whether factors that characterize the impacts of land use differentiate between different management practices. This indicates the importance of developing factors that characterize land use when considering management practices. 
Table 2. Comparison of land use inventory and impact results between different farming systems.

\begin{tabular}{|c|c|c|c|c|c|c|}
\hline & Number of Studies & $\begin{array}{c}\text { Comparison of Inventory Analysis } \\
\text { Results }{ }^{1} \\
\text { (Unit Used in Inventory Results }{ }^{2} \text { ) }\end{array}$ & $\begin{array}{c}\text { Comparison of Impact } \\
\text { Assessment Results } \\
{ }^{1} \\
\text { (Unit Used in Impact Results }{ }^{2} \text { ) }\end{array}$ & Indicators & Remarks & Reference \\
\hline \multirow{2}{*}{$\begin{array}{l}\text { Do not differentiate management } \\
\text { practices in impact assessment. }\end{array}$} & \multirow{2}{*}{2} & n.a. & 1.2 (Point/FU) & Ecosystem quality & -Area of land use is not shown. & [49] \\
\hline & & n.a. & 2.4 (Point/FU) & Ecosystem quality & Area of land use is not shown. & [53] \\
\hline \multirow{5}{*}{$\begin{array}{l}\text { Differentiate management } \\
\text { practices in impact assessment. }\end{array}$} & 5 & $3.2\left(\mathrm{~m}^{2} / \mathrm{FU}\right)$ & $2.4(\mathrm{DS} / \mathrm{FU})$ & Biodiversity & $\begin{array}{l}\text { CFs of extensive grassland: } 0.44 \\
\text { (dimensionless) } \\
\text { CFs of intensive grassland: } 0.65 \\
\text { (dimensionless) } \\
\text { CFs of intensive arable land: } 0.79 \\
\text { (dimensionless) }\end{array}$ & [54] \\
\hline & & $1.0\left(\mathrm{~m}^{2} / \mathrm{FU}\right)$ & $0.7\left(\mathrm{wS}_{100} / \mathrm{FU}\right)$ & Biodiversity & $\begin{array}{l}\text { CFs of extensive arable: } 7.6 \\
\quad\left(\mathrm{wS}_{100} / \text { (ha year)) }\right. \\
\text { CFs of intensive arable: } 11.7 \\
\quad\left(\mathrm{wS}_{100} / \text { (ha year) }\right)\end{array}$ & [55] \\
\hline & & $1.4\left(\mathrm{~m}^{2} / \mathrm{FU}\right)$ & $0.2(\mathrm{DS} / \mathrm{FU})$ & Biodiversity & $\begin{array}{c}\text { CFs of organic grassland: }-0.01 \\
\text { (dimensionless) } \\
\text { arable: } 0.36 \text { (dimensionless) } \\
\text { CFs of intensive grassland: } 0.65 \\
\text { (dimensionless) } \\
\text { arable: } 0.79 \text { (dimensionless) }\end{array}$ & [11] \\
\hline & & $1.9\left(\mathrm{~m}^{2} \cdot\right.$ year $\left./ \mathrm{FU}\right)$ & 0.5 (PDF/FU) & Biodiversity & $\begin{array}{c}\text { CFs of organic pasture: }-0.01\left(\mathrm{PDF} / \mathrm{m}^{2} \mathrm{a}\right) \\
\text { arable: } 0.2\left(\mathrm{PDF} / \mathrm{m}^{2} \mathrm{a}\right) \\
\text { CFs of conventional pasture: } 0.3\left(\mathrm{PDF} / \mathrm{m}^{2} \mathrm{a}\right) \\
\text { arable: } 0.6\left(\mathrm{PDF} / \mathrm{m}^{2} \mathrm{a}\right)\end{array}$ & [12] \\
\hline & & $1.8(\mathrm{ha} / \mathrm{FU})$ & $\begin{array}{c}2.3(\mathrm{t} / \mathrm{FU}) \\
-2.0(\mathrm{t} / \mathrm{FU}) \\
0.4(\mathrm{~m} 3 / \mathrm{FU})\end{array}$ & $\begin{array}{c}\text { Erosion } \\
\text { Organic matter } \\
\text { Compaction }\end{array}$ & $\begin{array}{l}\text {.Impacts are estimated based on a process } \\
\text { model using primary data. } \\
\text {.Minus value shows benefit. }\end{array}$ & [48] \\
\hline
\end{tabular}

${ }^{1}$ A ratio between results of organic (or extensive) and conventional (or intensive) systems (Organic/Conventional) are shown. Details are shown in Table S1. ${ }^{2}$ Abbreviations: FU, functional unit; DS, damage score; PDF, potentially disappeared fraction; wS100, weighted species richness in a standard area (100 m2); CF, characterization factor; n.a., data not available. 
Table 3. Characterization factors related to agricultural land use in life cycle impact assessment.

\begin{tabular}{|c|c|c|c|c|c|c|c|}
\hline & & Indicators & Unit ${ }^{1}$ & $\begin{array}{c}\text { Type of Land Use } \\
\text { Related to Agriculture }\end{array}$ & Regional Variation & $\begin{array}{c}\text { Differentiate } \\
\text { Management Practices }\end{array}$ & References \\
\hline Mid-point & Land use & $\begin{array}{l}\text { Distance-to-Nature-Potential } \\
\text { (DNP) }\end{array}$ & $\begin{array}{c}\text { Dimensionless } \\
\text { (value is shown between } 0 \\
\text { to } 1 . \text { Zero is closest to the } \\
\text { natural state) }\end{array}$ & $\begin{array}{l}\text { Agricultural land use } \\
\text { (Extensive, moderate } \\
\text { intensity, intensive) }\end{array}$ & Europe & $\begin{array}{l}\text { Yes. On extensive or } \\
\text { intensive level. } \\
\text { (Value }_{\text {intensive }}> \\
\text { Value }_{\text {extensive }} \text { ) }\end{array}$ & [56] \\
\hline \multirow{8}{*}{$\begin{array}{l}\text { Mid-point } \\
\sim \\
\text { End-point }\end{array}$} & \multirow{4}{*}{ Loss of biodiversity } & $\begin{array}{c}\text { Biodiversity Damage } \\
\text { Potential } \\
\text { (species diversity) }\end{array}$ & $\begin{array}{l}\text { Dimensionless } \\
\text { (Relative reduction in } \\
\text { species richness) }\end{array}$ & $\begin{array}{l}\text { Annual crops, permanent } \\
\text { crops }\end{array}$ & Global: 9 biomes & No. & [57] \\
\hline & & $\begin{array}{c}\text { Biodiversity Damage } \\
\text { Potential } \\
\text { (functional diversity) }\end{array}$ & $\begin{array}{c}\text { Dimensionless } \\
\text { (Relative reduction in } \\
\text { species functional } \\
\text { diversity) }\end{array}$ & $\begin{array}{c}\text { Fallow, field margins, } \\
\text { arable, permanent crop, } \\
\text { mosaic, (Extensive, } \\
\text { intensive) }\end{array}$ & $\begin{array}{l}\text { The Americas: } \\
21 \text { ecoregions }\end{array}$ & $\begin{array}{l}\text { Yes. On extensive or } \\
\text { intensive level. } \\
\text { (Value }_{\text {intensive }}> \\
\left.\text { Value }_{\text {extensive }}\right)\end{array}$ & [58] \\
\hline & & Relative species richness & $\begin{array}{l}\text { Dimensionless } \\
\text { (Relative reduction in } \\
\text { species richness) }\end{array}$ & $\begin{array}{c}\text { Annual crops, permanent } \\
\text { crops } \\
\text { (Extensive, intensive) }\end{array}$ & $\begin{array}{l}\text { Global: } \\
6 \text { biomes }\end{array}$ & $\begin{array}{l}\text { Yes. On extensive or } \\
\text { intensive level. } \\
\text { (Value }_{\text {intensive }}> \\
\left.\text { Value }_{\text {extensive }}\right)\end{array}$ & [59] \\
\hline & & $\begin{array}{l}\text { Regional and global species } \\
\text { richness }\end{array}$ & $\begin{array}{l}\text { Regional species lost } / \mathrm{m}^{2} \\
\text { Global species lost } / \mathrm{m}^{2}\end{array}$ & Arable, permanent crop & $\begin{array}{c}\text { Global: } \\
804 \text { ecoregions }\end{array}$ & No. & [60] \\
\hline & & $\begin{array}{l}\text { Biodiversity quality } \\
\text { (considering ecosystem } \\
\text { scarcity, vulnerability, } \\
\text { maintained biodiversity) }\end{array}$ & No $C F$ is provided & Agricultural land use & $\begin{array}{l}\text { Foreground } \\
\text { assessment }\end{array}$ & $\begin{array}{l}\text { Yes. On extensive or } \\
\text { intensive level. }\end{array}$ & [61] \\
\hline & \multirow{3}{*}{$\begin{array}{l}\text { Loss of ecosystem } \\
\text { services }\end{array}$} & $\begin{array}{l}\text { Biotic production potential } \\
\text { (Soil organic carbon } \\
\text { depletion) }\end{array}$ & ton C/ (ha-yr) & $\begin{array}{l}\text { Fallow, irrigated crops, } \\
\text { flooded crops, field } \\
\text { margins, permanent crops }\end{array}$ & $\begin{array}{c}\text { Global: } \\
10 \text { climate regions }\end{array}$ & $\begin{array}{l}\text { Yes. On management } \\
\text { practice level. } \\
\text { (type of fertilizer, tillage } \\
\text { practice) }\end{array}$ & [62] \\
\hline & & $\begin{array}{l}\text { Biotic production potential } \\
\text { (Soil organic carbon } \\
\text { depletion) }\end{array}$ & $\mathrm{kgC} /\left(\mathrm{m}^{2}-\mathrm{yr}\right)$ & $\begin{array}{l}\text { Cultivated and Managed } \\
\text { Vegetation }\end{array}$ & $\begin{array}{l}\text { Europe: } \\
34 \text { ecoregions }\end{array}$ & $\begin{array}{c}\text { No. } \\
\text { (mentioned as a } \\
\text { limitation) }\end{array}$ & [63] \\
\hline & & Climate Regulation Potential & $\begin{array}{l}\text { Fossil-combustion-equivalent } \\
\text { ton C per hectare } \\
\text { transferred to air (Ceq.) }\end{array}$ & Cropland & $\begin{array}{c}\text { Global: } \\
9 \text { climate regions }\end{array}$ & No. & [64] \\
\hline
\end{tabular}


Table 3. Cont

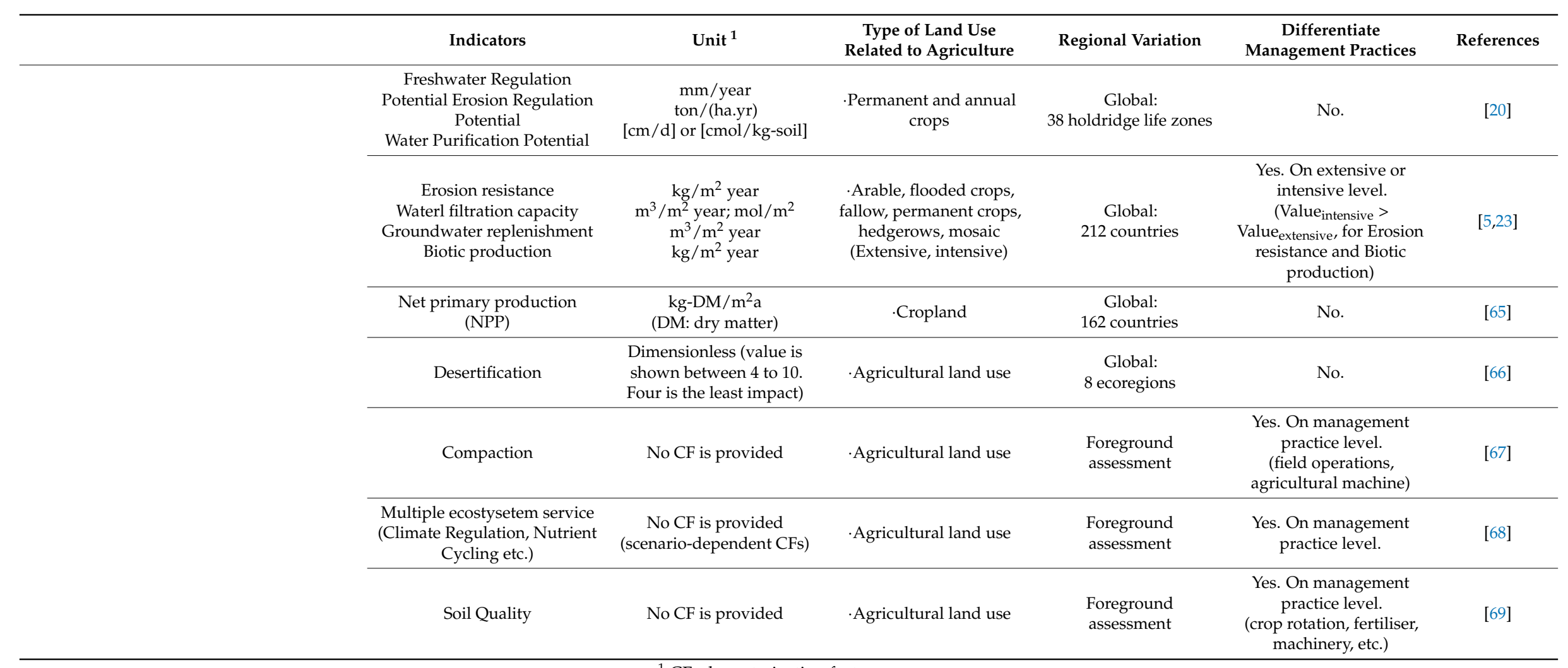

${ }^{1} \mathrm{CF}$ : characterization factors. 


\subsection{Results and Insights from Survey (2)}

In general, the main impacts that are considered in a land use impact category were losses of biodiversity and ecosystem services (Table 3). In a total of 21 articles, one study developed factors at a midpoint level, remain eight and twelve studies developed factors for biodiversity and ecosystem services impact, respectively. For biodiversity, three studies had been updated, and therefore, the remaining five articles were shown in Table 3. Indicators of biodiversity mainly focus on species richness and extinction risk. From the perspective of differences in management practices, two studies calculated factors at an extensive or intensive level. In both cases, the factor was smaller for extensive than for intensive levels. For more details, please refer to studies by Teixeira et al. [70] and De Souza et al. [71], which are organized with regard to the recent development of indicators of biodiversity. A summary of the issues related to the ecosystem service factors related to land use is provided.

For ecosystem services, because two studies were updated, the remaining ten articles were shown in Table 3. With respect to various ecosystem services, although primarily services that are related to soil quality and some of the regulatory services were considered, those unique to agriculture were missing, e.g., pollination, pest control, soil formation and composition, habitat conservation/gene resources, and agricultural landscaping. Pollination and pest control have a large influence on pesticide management and are closely related to land use through landscape management (Table 1). Currently, ecosystem services whose mechanism is well understood and easy to quantify are preferred for development [18]. In the case of pollination, an assessment framework in LCA has finally begun to be examined [72]. It will be necessary to quantify ecosystem services (pollination, pest control, etc.), which are characteristic of agriculture, in the future.

Factors are estimated on three levels, land use type (e.g., annual crops, permanent crops, and flooded crops), intensity (e.g., intensive, extensive), and management practice. Currently, most of the factors are developed at the level of land use type. Factors at the level of management practice are only present in the study by Brandão and Milà i Canals [62] who focused on soil organic carbon depletion. Some factors (erosion, water filtration, etc.) were calculated at the intensity level (intensive or extensive) of land use [23]. Factors at the level of land use type are useful for assessing a case where land use occurs in distinct types, such as agriculture, forestry, and pasture. However, when attempting to detect differences between management practices for agricultural production, a factor at the level of land use type is powerless; therefore, a factor at the level of management practice is desirable. The intensity level is frequently used for the factors of impacts on biodiversity (Table 3). However, in the case of ecosystem services, differences between management practices may not be properly assessed depending on the item subject to the assessment. For example, in the case of soil erosion prevention, the impact greatly differs depending on the cultivation method used on an inclined plane, but it is impossible for this classification (intensive or extensive) to reflect all differences in management practices on an inclined surface.

Process models were used in factor calculation at intensity level. LANCA $[5,23]$ estimated factors that are related to carbon storage, groundwater regeneration, and preventing soil erosion at an extensive or intensive level; detailed assessment based on management practices can be performed when local data is available. Although no factor was provided, process models were used for foreground assessment. Joensuu and Saarinen [48] assessed the impacts of compaction using the COMPSOIL model [73]. Arbault [68] quantified local climate regulation, nutrient cycling, etc. using an integrated model. The above indicates that factors at the level of management practice are possible to be calculated if a process model is used in these factor calculations, although many of the factors are currently calculated at the level of intensity. 


\section{Prospects of Assessment of Impact of Land Use on Ecosystem Services}

\subsection{Development of Factors That Characterize Land Use at a Management Practice Level}

Numerous currently available factors that characterize land use are at an extensive or intensive level $[5,23]$. However, some cases exist where it is difficult to rigidly classify the targeted land use in either of these two categories. Depending on the ecosystem service, intensity levels of land use do not always express differences at the level of management practice (refer to Section 4.2). Therefore, development of factors at management level is important for comparatively evaluating agricultural production systems during LCA.

The development of land use factors for ecosystem services according to the management practices is possible using process modeling-based models. Ecosystem services (e.g., soil carbon storage and soil erosion prevention) can be assessed through the following steps using process modeling-based models. First, because agricultural production systems vary widely, land use types, such as permanent and flooded crops, can be categorized. Then, key management practices that have a strong effect on targeted ecosystem services for each land use type can be identified based on the relationship between ecosystem services and management practices (Table 1). Finally, factors that characterize are calculated according to the combination of key management practices based on a process modeling-based model that can consider these practices.

However, estimation of factors that characterize land use at the management practice level is still limited to ecosystem services that can be quantified using a modeling-based approach [18]. A high demand also exists for inventory data when applying the estimated factors that characterize the impacts of land use to LCA case studies [48,74]. Data are required not only regarding the cultivation location and area but also regarding management practices.

\subsection{Collecting and Accumulating Foreground Data}

Because it is currently difficult to estimate factors that characterize effects of land use of ecosystem services, such as pollination, pest control, and habitat conservation [18,72], it is important to incorporate the foreground evaluation of impact of land use on these ecosystem services. In general, a qualitative or semi-quantitative evaluation method based on the judgment of experts [69] or an evaluation method based on field surveys could be considered [75].

The qualitative method was used when it was difficult to quantitatively demonstrate differences among management practices. For example, the Swiss Agricultural Life Cycle Assessment proposed a semi-quantitative method for evaluating soil quality with different management systems [69]. Data collected were semi-quantitatively evaluated for different management systems based on expert opinion. Because regional production and management technology may influence expert opinions on differences among management practices, this method requires the development of a regional version that incorporates regional knowledge.

The later method is used for estimating impacts directly based on data obtained by field surveys that consider different management practices. Through the accumulation of evaluation cases, it is possible to contribute to the estimation of factors that characterize land use in the future. However, the following two points should be noted when specifying differences in management practices based on data collected. One is that factors influencing land use are greatly affected by the ecosystem surrounding the farmland $[3,75]$. Therefore, to determine differences among management practices, devices are required that will pre-align with the surrounding ecosystem (e.g., extent of mountains, plains, or mosaic landscapes). The other one is that response time must be considered when collecting data [27]. Because it takes time for ecosystem services to respond to changes in management practices, a sufficient time period must be considered for the targeted ecosystem services to respond to changes in management practices. 


\section{Conclusions}

An agricultural LCA should to consider the impact of management practices on ecosystem services. It is difficult for the current ecosystem service factors, which are derived from land use, to contribute to the selection of environmentally friendly management practices because they are barely able to show differences among management practices. This study investigated the evaluation of land use in LCA case studies, along with factors that characterize land use and revealed challenges that are encountered at the level of management practice. The results show that the number of agricultural LCA cases where land use impacts instead of land area were assessed was still small. The results of limited LCA case studies, that using factors could differentiate between various management practices, suggest that although organic farming methods have been employed over large land areas, lower damage may be caused by agricultural land use. For factors that have developed in existing research, services related to soil quality and some of the regulatory services were considered, those unique to agriculture were missing. Although most of factors were calculated at levels of intensity or land use type, some of them were based on a process-based model that could consider management practices.

The future challenges are summarized below. First, because management practices and ecosystem services are closely related, factors that characterize the effects of land use on ecosystem services should be calculated at the level of management practices. Second, for services that are relatively easy to quantify, factors can be calculated at the level of management practice using the modeling-based ecological model. Finally, for ecosystem services that are difficult to evaluate using a modeling approach, a foreground evaluation based on field surveys could be performed. The accumulation of foreground data from the evaluations will contribute to evaluating factors that characterize the effect of land use at the level of management practice.

Supplementary Materials: The following are available online at http:/ /www.mdpi.com/2071-1050/10/3/630/s1: Table S1, Land use inventory results and impact assessment results in case studies of agricultural LCA.

Acknowledgments: This research received no specific grant from any funding agency in the public, commercial, or not-for-profit sectors.

Author Contributions: The text of this manuscript was written by Longlong Tang, with contributions by Kiyotada Hayashi, Kazunori Kohyama, and Ai Leon. Data collection was performed by Longlong Tang. The research was supervised by Kiyotada Hayashi, Kazunori Kohyama, and Ai Leon. All authors proofread and approved the final manuscript.

Conflicts of Interest: The authors declare no conflict of interest.

\section{References}

1. MEA. Ecosystems and Human Well-Being: Synthesis; Island Press: Washington, DC, USA, 2005.

2. TEEB. The Economics of Ecosystems and Biodiversity: Mainstreaming the Economics of Nature: A Synthesis of the Approach, Conclusions and Recommendations of TEEB; UNEP: Nairobi, Kenya, 2010.

3. Power, A.G. Ecosystem services and agriculture: Tradeoffs and synergies. Philos. Trans. R. Soc. B Biol. Sci. 2010, 365, 2959-2971. [CrossRef] [PubMed]

4. Huang, J.; Tichit, M.; Poulot, M.; Darly, S.; Li, S.; Petit, C.; Aubry, C. Comparative review of multifunctionality and ecosystem services in sustainable agriculture. J. Environ. Manag. 2015, 149, 138-147. [CrossRef] [PubMed]

5. Beck, T.; Bos, U.; Wittstock, B.; Baitz, M.; Fischer, M.; Sedlbauer, K. LANCA—Land Use Indicator Value Calculation in Life Cycle Assessment. 2010. Available online: http:/ / publica.fraunhofer.de/eprints/urn: nbn:de:0011-n-1435418.pdf (accessed on 3 June 2017).

6. Araya, T.; Cornelis, W.M.; Nyssen, J.; Govaerts, B.; Bauer, H.; Gebreegziabher, T.; Oicha, T.; Raes, D.; Haile, M.; Dechers, J. Effects of conservation agriculture on runoff, soil loss and crop yield under rainfed conditions in Tigray, Northern Ethiopia. Soil Use Manag. 2011, 27, 404-414. [CrossRef]

7. Stafford, J.; Kaminski, R.; Reinecke, K. Avian Foods, Foraging and Habitat Conservation in World Rice Fields. Waterbirds 2010, 33, 133-150. [CrossRef] 
8. Strum, K.; Reiter, M.; Hartman, C.A.; Iglecia, M.; Kelsey, T.R.; Hickey, C. Winter management of California's rice fields to maximize waterbird habitat and minimize water use. Agric. Ecosyst. Environ. 2013, 179, 116-124. [CrossRef]

9. Niang, A.; Pernollet, C.; Gauthier-Clerc, M.; Guillemain, M. A cost-benefit analysis of rice field winter flooding for conservation purposes in Camargue, Southern France. Agric. Ecosyst. Environ. 2016, 231, $193-205$. [CrossRef]

10. TEEB. TEEB for Agriculture \& Food: An Interim Report; UNEP: Geneva, Switzerland, 2015.

11. Guerci, M.; Knudsen, M.T.; Bava, L.; Zucali, M.; Schönbach, P.; Kristensen, T. Parameters affecting the environmental impact of a range of dairy farming systems in Denmark, Germany and Italy. J. Clean. Prod. 2013, 54, 133-141. [CrossRef]

12. Mueller, C.; de Baan, L.; Koellner, T. Comparing direct land use impacts on biodiversity of conventional and organic milk-Based on a Swedish case study. Int. J. Life Cycle Assess. 2014, 19, 52-68. [CrossRef]

13. Hayashi, K. Practical recommendations for supporting agricultural decisions through life cycle assessment based on two alternative views of crop production: The example of organic conversion. Int. J. Life Cycle Assess. 2013, 18, 331-339. [CrossRef]

14. Leach, A.M.; Emery, K.A.; Gephart, J.; Davis, K.F.; Erisman, J.W.; Leip, A.; Pace, M.L.; D’Odorico, P.; Carr, J.; Noll, L.C.; et al. Environmental impact food labels combining carbon, nitrogen, and water footprints. Food Policy 2016, 61, 213-223. [CrossRef]

15. Manfredi, S.; Allacker, K.; Chomkhamsri, K.; Pelletier, N.; de Souza, D.M. Product Environmental Footprint (PEF) Guide; European Commission Joint Research Centre: Ispra, Italy, 2012.

16. European Commission-Joint Research Centre-Institute for Environment and Sustainability. International Reference Life Cycle Data System (ILCD) Handbook-Recommendations Based on Existing Environmental Impact Assessment Models and Factors for Life Cycle Assessment in a European Context; Publications Office of the European Union: Luxembourg, 2011.

17. Zhang, Y.I.; Singh, S.; Bakshi, B.R. Accounting for ecosystem services in life cycle assessment part I: A critical review. Environ. Sci. Technol. 2010, 44, 2232-2242. [CrossRef] [PubMed]

18. Othoniel, B.; Rugani, D.; Heijungs, R.; Benetto, E.; Withagen, C. Assessment of Life Cycle Impacts on Ecosystem Services: Promise, Problems, and Prospects. Environ. Sci. Technol. 2016, 50, 1077-1092. [CrossRef] [PubMed]

19. Koellner, T.; de Baan, L.; Beck, T.; Brandão, M.; Civit, B.; Margni, M.; Canals, L.M.; Saad, R.; de Souza, D.M.; Müller-Wenk, R. UNEP-SETAC guideline on global land use impacts on biodiversity and ecosystem services in LCA. Int. J. Life Cycle Assess. 2013, 18, 1188-1202. [CrossRef]

20. Saad, R.; Koellner, T.; Margni, M. Land use impacts on freshwater regulation, erosion regulation and water purification: A spatial approach for a global scale. Int. J. Life Cycle Assess. 2013, 18, 1253-1264. [CrossRef]

21. Hauschild, M.Z.; Huijbregts, M.A.J. Life Cycle Impact Assessment, LCA Compendium-The Complete World of Life Cycle Assessment; Springer-Science + Business Media BV: Dordrecht, The Netherlands, 2015.

22. Canals, L.M.; Bauer, C.; Depestele, J.; Dubreuil, A.; Freiermuth, K.R.; Gaillard, G.; Michelsen, O.; Müller-Wenk, R.; Rydgren, B. Key elements in a framework for land use impact assessment in LCA. Int. J. Life Cycle Assess. 2007, 12, 5-15. [CrossRef]

23. Bos, U.; Horn, R.; Beck, T.; Lindner, J.P.; Fischer, M. LANCA ${ }^{\circledR}$ —Characterisation Factors for Life Cycle Impact Assessment, Version 2.0; Fraunhofer Verlag: Stuttgart, Germany, 2016; ISBN 978-3-8396-0953-8.

24. Vidal-Legaz, B.; Sala, S.; Antón, A.; de Souza, D.M.; Nocita, M.; Putman, B.; Teixeira, R.F.M. Land-Use Related Environmental Indicators for Life Cycle Assessment; JRC Technical Report; Publications Office of the European Union: Luxembourg, 2016. [CrossRef]

25. Meier, M.S.; Stoessel, F.; Jungbluth, N.; Juraske, R.; Schader, C.; Stolze, M. Environmental impacts of organic and conventional agricultural products-Are the differences captured by life cycle assessment? J. Environ. Manag. 2015, 149, 193-208. [CrossRef] [PubMed]

26. TEEB. The Economics of Ecosystems and Biodiversity Ecological and Economic Foundations; Earthscan: London, UK; Washington, DC, USA, 2010.

27. Robertson, G.P.; Gross, K.L.; Hamilton, S.K.; Landis, D.A.; Schmidt, T.M.; Snapp, S.S.; Swinton, S.M. Farming for Ecosystem Services: An Ecological Approach to Production Agriculture. BioScience 2014, 64, 404-415. [CrossRef] [PubMed] 
28. Cao, V.; Margni, M.; Favis, B.D.; Deschênes, L. Aggregated indicator to assess land use impacts in life cycle assessment (LCA) based on the economic value of ecosystem services. J. Clean. Prod. 2015, 94, 56-66. [CrossRef]

29. Farber, S.C.; Costanza, R.; Wilson, M.A. Economic and ecological concepts for valuing ecosystem services. Ecol. Econ. 2002, 41, 375-392. [CrossRef]

30. Eigenbrod, F.; Armsworth, P.R.; Anderson, B.J.; Heinemeyer, A.; Gillings, S.; Roy, D.B.; Thomas, C.D.; Gaston, K.J. The impact of proxy-based methods on mapping the distribution of ecosystem services. J. Appl. Ecol. 2010, 47, 377-385. [CrossRef]

31. Maes, J.; Egoh, B.; Willemen, L.; Liquete, C.; Vihervaara, P.; Schägner, J.P.; Grizzetti, B.; Drakou, E.G.; Notte, A.L.; Zulian, G.; et al. Mapping ecosystem services for policy support and decision making in the European Union. Ecosyst. Serv. 2012, 1, 31-39. [CrossRef]

32. Martínez-Harms, M.J.; Balvanera, P. Methods for mapping ecosystem service supply: A review. Int. J. Biodivers. Sci. Ecosyst. Serv. Manag. 2012, 8, 17-25. [CrossRef]

33. Crossman, N.D.; Burkhard, B.; Nedkov, S.; Willemen, L.; Petz, K.; Palomo, I.; Drakou, E.G.; Martín-Lopez, B.; McPhearson, T.; Boyanova, K.; et al. A blueprint for mapping and modelling ecosystem services. Ecosyst. Serv. 2013, 4, 4-14. [CrossRef]

34. Egoh, B.; Dunbar, M.B.; Maes, J.; Willemen, L.; Drakou, E.G. Indicators for Mapping Ecosystem Services: A Review; Publications Office of the European Union: Luxembourg, 2012; Available online: http:/ / publications.jrc.ec. europa.eu/repository/bitstream/JRC73016/lbna25456enn.pdf (accessed on 13 June 2017).

35. Lavorel, S.; Grigulis, K.; Lamarque, P.; Colace, M.; Garden, D.; Girel, J.; Pellet, G.; Douzet, R. Using plant functional traits to understand the landscape distribution of multiple ecosystem services. J. Ecol. 2011, 99, 135-147. [CrossRef]

36. Jenkinson, D.S.; Coleman, K. The turnover of organic carbon in subsoils. Part 2. Modelling carbon turnover. Eur. J. Soil Sci. 2008, 59, 400-413. [CrossRef]

37. Yagasaki, Y.; Shirato, Y. Assessment on the rates and potentials of soil organic carbon sequestration in agricultural lands in Japan using a process-based model and spatially explicit land-use change inventories-Part 1: Historical trend and validation based on nation-wide soil monitoring. Biogeosciences 2014, 11, 4429-4442.

38. Flanagan, D.C.; Gilley, J.E.; Franti, T.G. Water Erosion Prediction Project (WEPP): Development history, model capabilities, and future enhancements. Trans. Am. Soc. Agric. Biol. Eng. 2007, 50, 1603-1612. [CrossRef]

39. Jeanneret, P.; Baumgartner, D.U.; Knuchel, R.F.; Koch, B.; Gaillard, G. An expert system for integrating biodiversity into agricultural life-cycle assessment. Ecol. Indic. 2014, 46, 224-231. [CrossRef]

40. Daily, G.C.; Polasky, S.; Goldstein, J.; Kareiva, P.M.; Mooney, H.A.; Pejchar, L.; Ricketts, T.H.; Salzman, J.; Shallenberger, R. Ecosystem services in decision making: Time to deliver. Front. Ecol. Environ. 2009, 7, 21-28. [CrossRef]

41. Boumans, R.; Roman, J.; Altman, I.; Kaufman, L. The Multiscale Integrated Model of Ecosystem Services (MIMES): Simulating the interactions of coupled human and natural systems. Ecosyst. Serv. 2015, 12, 30-41. [CrossRef]

42. Villa, F.; Bagstad, K.J.; Voigt, B.; Johnson, G.W.; Portela, R.; Honzak, M.; Batker, D. A methodology for adaptable and robust ecosystem services assessment. PLoS ONE 2014, 9, e91001. [CrossRef] [PubMed]

43. Guerry, A.D.; Tallis, H. Marine ecosystem services: A framework and practical set of tools for ecosystem-based management. In Marine Ecosystem-Based Management; Fogarty, M.J., McCarthy, J.J., Eds.; Harvard University Press: Cambridge, MA, USA, 2014; p. 217.

44. Anton, A.; Torrellas, M.; Núñez, M.; Sevigné, E.; Amores, M.J.; Muñoz, P.; Montero, J.I. Improvement of Agricultural Life Cycle Assessment Studies through Spatial Differentiation and New Impact Categories: Case Study on Greenhouse Tomato Production. Environ. Sci. Technol. 2014, 48, 9454-9462. [CrossRef] [PubMed]

45. Canals, L.M.; Rigarlsford, G.; Sim, S. Land use impact assessment of margarine. Int. J. Life Cycle Assess. 2013, 18, 1265-1277. [CrossRef]

46. Mattila, T.; Helin, T.; Antikainen, R. Land use indicators in life cycle assessment-A case study on beer production. Int. J. Life Cycle Assess. 2012, 17, 277-286. [CrossRef] 
47. Nordborg, M.; Sasu-Boakye, Y.; Cederberg, C.; Berndes, G. Challenges in developing regionalized characterization factors in land use impact assessment: Impacts on ecosystem services in case studies of animal protein production in Sweden. Int. J. Life Cycle Assess. 2017, 22, 328-345. [CrossRef]

48. Joensuu, K.; Saarinen, M. Applying soil quality indicators in the context of life cycle assessment in a Finnish case study. Int. J. Life Cycle Assess. 2017, 22, 1339-1353. [CrossRef]

49. Mohamad, R.S.; Verrastro, V.; Cardone, G.; Bteich, M.R.; Favia, M.; Moretti, M.; Roma, R. Optimization of organic and conventional olive agricultural practices from a Life Cycle Assessment and Life Cycle Costing perspectives. J. Clean. Prod. 2014, 70, 78-89. [CrossRef]

50. Nemecek, T.; Dubois, D.; Huguenin-Elie, O.; Gaillard, G. Life cycle assessment of Swiss farming systems: I. Integrated and organic farming. Agric. Syst. 2011, 104, 217-232. [CrossRef]

51. Parajuli, R.; Knudsen, M.T.; Djomo, S.N.; Corona, A.; Birkved, M.; Dalgaard, T. Environmental life cycle assessment of producing willow, alfalfa and straw from spring barley as feedstocks for bioenergy or biorefinery systems. Sci. Total Environ. 2017, 586, 226-240. [CrossRef] [PubMed]

52. Brandão, M.; Canals, L.M.; Clift, R. Soil organic carbon changes in the cultivation of energy crops: Implications for GHG balances and soil quality for use in LCA. Biomass Bioenergy 2011, 35, 2323-2336. [CrossRef]

53. Foteinis, S.; Chatzisymeon, E. Life cycle assessment of organic versus conventional agriculture. A case study of lettuce cultivation in Greece. J. Clean. Prod. 2016, 112, 2462-2471. [CrossRef]

54. Battini, F.; Agostini, A.; Tabaglio, V.; Amaducci, S. Environmental impacts of different dairy farming systems in the PoValley. J. Clean. Prod. 2016, 112, 91-102. [CrossRef]

55. Sandin, G.; Peters, GM.; Svanström, M. Moving down the cause-effect chain of water and land use impacts: An LCA case study of textile fibres. Resour. Conserv. Recycl. 2013, 73, 104-113. [CrossRef]

56. Fehrenbach, H.; Grahl, B.; Giegrich, J.; Busch, M. Hemeroby as an impact category indicator for the integration of land use into life cycle (impact) assessment. Int. J. Life Cycle Assess. 2015, 20, 1511-1527. [CrossRef]

57. De Baan, L.; Mutel, C.L.; Curran, M.; Hellweg, S.; Koellner, T. Land Use in Life Cycle Assessment: Global Factors used to characterize Based on Regional and Global Potential Species Extinction. Environ. Sci. Technol. 2013, 47, 9281-9290. [CrossRef] [PubMed]

58. Souza, M.D.; Flynn, D.; de Clerck, F.; Rosenbaum, R.; de Melo, L.H.; Koellner, T. Land use impacts on biodiversity in LCA: Proposal of factors used to characterize based on functional diversity. Int. J. Life Cycle Assess. 2013, 18, 1231-1242. [CrossRef]

59. Elshout, P.M.; van Zelm, R.; Karuppiah, R.; Laurenzi, I.J.; Huijbregts, M.A. A spatially explicit data-driven approach to assess the effect of agricultural land occupation on species groups. Int. J. Life Cycle Assess. 2014, 19, 758-769. [CrossRef]

60. Chaudhary, A.; Verones, F.; de Baan, L.; Hellweg, S. Quantifying Land Use Impacts on Biodiversity: Combining Species-Area Models and Vulnerability Indicators. Environ. Sci. Technol. 2015, 49, 9987-9995. [CrossRef] [PubMed]

61. Coelho, C.R.; Michelsen, O. Land use impacts on biodiversity from kiwifruit production in New Zealand assessed with global and national datasets. Int. J. Life Cycle Assess. 2014, 19, 285-296. [CrossRef]

62. Brandão, M.; Canals, L.M. Global characterisation factors to assess land use impacts on biotic production. Int. J. Life Cycle Assess. 2013, 18, 1243-1252. [CrossRef]

63. Morais, T.G.; Domingos, T.; Teixeira, R.F. A spatially explicit life cycle assessment midpoint indicator for soil quality in the European Union using soil organic carbon. Int. J. Life Cycle Assess. 2016, 21, 1076-1091. [CrossRef]

64. Müller-Wenk, R.; Brandão, M. Climatic impact of land use in LCA-Carbon transfers between vegetation/soil and air. Int. J. Life Cycle Assess. 2010, 15, 172-182. [CrossRef]

65. Alvarenga, R.A.; Erb, K.H.; Haberl, H.; Soares, S.R.; van Zelm, R.; Dewulf, J. Global land use impacts on biomass production-A spatial-differentiated resource-related life cycle impact assessment method. Int. J. Life Cycle Assess. 2015, 20, 440-450. [CrossRef]

66. Núñez, M.; Civit, B.; Muñoz, P.; Arena, A.P.; Rieradevall, J.; Antón, A. Assessing potential desertification environmental impact in life cycle assessment. Int. J. Life Cycle Assess. 2010, 15, 67-78. [CrossRef]

67. Garrigues, E.; Corson, M.; Angers, D.; Werf, H.G.; Walter, C. Development of a soil compaction indicator in life cycle assessment. Int. J. Life Cycle Assess. 2013, 18, 1316-1324. [CrossRef] 
68. Arbault, D.; Rivière, M.; Rugani, B.; Benetto, E.; Tiruta-Barna, L. Integrated earth system dynamic modeling for life cycle impact assessment of ecosystem services. Sci. Total Environ. 2014, 472, 262-272. [CrossRef] [PubMed]

69. Oberholzer, H.R.; Freiermuth Knuchel, R.; Weisskopf, P.; Gaillard, G. A novel method for soil quality in life cycle assessment using several soil indicators. Agron. Sustain. Dev. 2012, 32, 639-649. [CrossRef]

70. Teixeira, R.F.M.; de Souza, D.M.; Curran, M.P.; Antón, A.; Michelsen, O.; Canals, L.M. Towards consensus on land use impacts on biodiversity in LCA: UNEP/SETAC Life Cycle Initiative preliminary recommendations based on expert contributions. J. Clean. Prod. 2015, 112, 4283-4287. [CrossRef]

71. De Souza, M.D.; Teixeira, R.F.; Ostermann, O.P. Assessing biodiversity loss due to land use with Life Cycle Assessment: Are we there yet? Glob. Chang. Biol. 2015, 21, 32-47. [CrossRef] [PubMed]

72. Crenna, E.; Sala, S.; Polce, C.; Collina, E. Pollinators in life cycle assessment: Towards a framework for impact assessment. J. Clean. Prod. 2017, 140, 399-409. [CrossRef]

73. O'Sullivan, M.F.; Henshall, J.K.; Dickson, J.W. A simplified method for estimating soil compaction. Soil Tillage Res. 1999, 49, 325-335. [CrossRef]

74. Piastrellini, R.; Civit, B.M.; Arena, A.P. Influence of Agricultural Practices on Biotic Production Potential and Climate Regulation Potential. A Case Study for Life Cycle Assessment of Soybean (Glycine max) in Argentina. Sustainability 2015, 7, 4386-4410. [CrossRef]

75. Tsutsui, M.H.; Tanaka, K.; Baba, Y.; Miyashita, T. Spatio-Temporal dynamics of generalist predators (Tetragnatha spider) in environmentally friendly paddy fields. Appl. Entomol. Zool. 2016, 51, 631-640. [CrossRef]

(C) 2018 by the authors. Licensee MDPI, Basel, Switzerland. This article is an open access article distributed under the terms and conditions of the Creative Commons Attribution (CC BY) license (http://creativecommons.org/licenses/by/4.0/). 